\title{
Entre coisas selvagens, monstros e feras: as traduções de Where The Wild Things Are para o português brasileiro e para o chinês
}

\section{Among wild things, monsters and beasts: the translations of Where The Wild Things Are into Brazilian Portuguese and Chinese}

A book is really like a lover. It arranges itself in your life in a way that is beautiful. Maurice Sendak

Jamilly Brandão Alvino*

* Mestranda em Letras Estrangeiras e Tradução, subárea Tradução e Linguística de Corpus na Universidade de São Paulo. Bolsista CAPES. Editora da Revista Zi Yue. Bacharela em Letras, habilitações português e chinês, pela Universidade de São Paulo.

E-mail: brandao.jamilly@gmail.com

TradTerm, São Paulo, v.37, n. 2, janeiro/2021, p. 563-595

Número Especial - Linguística de Corpus 
Resumo: No presente artigo, relatamos a construção e análise inicial de um corpus paralelo composto por um livro infantil escrito originalmente em inglês por Maurice Sendak, Where the Wild Things Are, e suas traduções para o português brasileiro e para o chinês, a fim de analisar e comparar as traduções publicadas nas duas línguas. A extração inicial de informações desse corpus está pautada na metodologia da Linguística de Corpus, e, almejando uma análise objetiva, foi utilizado o software WordSmith Tools. Após a exploração do corpus, a fim de entender as escolhas tradutológicas para a expressão 'wild things', bem como verificar sua possível tradução literal, julgou-se necessário contatar a tradutora Heloisa Jahn e elaborar uma entrevista proposta a onze falantes nativos de chinês. Os dados obtidos revelaram a similaridade entre as duas traduções.

Palavras-chave: Linguística de Corpus; Tradução; Literatura Infantil; Maurice Sendak; Domesticação; Estrangeirização.

Abstract: This paper studies a parallel corpus of a children's book originally written in English by Maurice Sendak, Where the Wild Things Are, and its translations into Brazilian Portuguese and Chinese, aiming to analyze and compare the translations published in both languages. Corpus Linguistics was the methodology used in this research and WordSmith Tools the software of choice. After the processing the corpus, in order to understand the translational strategies used for the phrase 'wild things', as well as to verify its possible literal translation, the Brazilian Portuguese translator, Heloisa Jahn, was contacted and an interview questionnaire was submitted to and answered by eleven native Chinese speakers. The data obtained revealed similarities between the two translations.

Keywords: Corpus Linguistics; Translation; Children's Literature; Maurice Sendak; Domestication; Foreignization.

TradTerm, São Paulo, v.37, n. 2, janeiro/2021, p. 563-595

Número Especial - Linguística de Corpus

www.revistas.usp.br/tradterm 


\section{Introdução}

A Linguística de Corpus é uma abordagem empírica utilizada nas mais variadas áreas de estudos, como lexicologia, análise do discurso, ensino de línguas, entre outros. Além de analisar e descrever as línguas, desde a década de 1990 a Linguística de Corpus vem sendo usada para investigar os aspectos universais das traduções, os estilos dos tradutores e os aspectos ideológicos apresentados por eles, colaborando também com os Estudos da Tradução ao ser aplicada como metodologia de pesquisa não somente na teoria, como também na prática tradutológica (FANTINUOLI; ZANETTIN, 2015).

A Linguística de Corpus ocupa-se da coleta e da exploração de textos reunidos em corpora por meio do uso de ferramentas computacionais. De acordo com Baker (1995: 225 apud TAGNIN; TEIXEIRA, 2004: 321, tradução nossa $\left.{ }^{1}\right)$, corpus designa:

(...) uma coletânea de textos em formato legível por máquina e que possa ser analisada semi-automaticamente ou automaticamente nos mais variados modos (...) ela é formada de acordo com um propósito, seguindo critérios que garantam a representatividade de determinada área ou a amostra de determinada língua $(. . .)^{2}$

Ao encontro da explanação de Baker, a presente pesquisa tem como corpus o livro infantil Where the Wild Things Are (1963), escrito pelo renomado autor estadunidense Maurice Sendak, e suas traduções para o português brasileiro - Onde vivem os monstros (2014, segunda edição), e para o chinês -Yěshòu chūmò de difāng 野兽出没的地方 (2009) ${ }^{3}$, compondo, assim, um corpus paralelo.

Where the Wild Things Are é a obra mais conhecida de Sendak, tendo sido adaptada para a televisão em $1974^{4}$, para o teatro em $1984^{5}$ e para o

\footnotetext{
${ }^{1}$ Todas as traduções aqui apresentadas serão de nossa autoria.

${ }^{2}$ Citação original: “(...) a collection of texts held in machine-readable form and capable of being analysed automatically or semi-automatically in a variety of ways (...) it is put together for a particular purpose and according to explicit design criteria in order to ensure that it is representative of the given area or sample of language it aims to account for (...).

3 Tradução literal: "O lugar onde a fera aparece e desaparece". Ressalta-se que, embora em alguns contextos o verbo chūmò 出没 signifique assombrar ou habitar, o conceituado dicionário Xiàndài hànyǔ cídiăn 现代汉语词典 (2012:178) explicita que esse vocábulo significa chūxiàn hé yǐncáng 出现和隐藏 - aparecer e desaparecer.

${ }^{4}$ Disponível em: https://youtu.be/EzKVvbR6jSw

${ }^{5}$ Informações em: https://www.glyndebourne.com/opera
}

TradTerm, São Paulo, v.37, n. 2, janeiro/2021, p. 563-595

Número Especial - Linguística de Corpus

www.revistas.usp.br/tradterm 
cinema em 20096. Com tamanho sucesso, a obra foi traduzida para mais de 20 idiomas, entre eles, o português brasileiro e o chinês. Parte daí a ideia de analisar e comparar as traduções publicadas nas duas línguas, tendo em vista as diferenças ${ }^{7}$ entre os hábitos culturais do Brasil e da China, assim como entre a gramática e fonologia das respectivas línguas.

Ressalta-se que o estudo aqui proposto utilizou a abordagem de direcionamento pelo corpus e, portanto, desenvolveu-se de acordo com dados extraídos a partir dele durante o processamento e a análise linguística (TAGNIN 2015: 323).

Na seção 2, serão apresentados o autor e a obra escolhidos, bem como um breve panorama histórico das traduções estudadas. Na seção 3, destacaremos os pressupostos teóricos sobre literatura infantil, picture books ${ }^{8}$ e tradução que norteiam o estudo, bem como as estratégias tradutológicas que serão utilizadas. A seção 4 conta com a elucidação da metodologia, enquanto a seção 5 a apresentará aplicada às etapas do processo de análise, expondo, ainda, as dificuldades encontradas e exemplos de resultados. Por fim, as Considerações Finais encerrarão o artigo.

\section{Maurice Sendak e Where the Wild Things Are}

Escritor e ilustrador de obras mundialmente conhecidas como In the Night Kitchen (1970), Seven Little Monsters (1977) e Outside Over There (1981), Maurice Bernard Sendak (1928-2012) obteve os mais diversos prêmios e honrarias durante a sua carreira, entre eles: a nomeação de uma escola de educação infantil na Califórnia, as medalhas Caldecott e Laura Ingalls Wilder, o prêmio Astrid Lindgren Memorial Award e o doutorado honorário da Universidade de Princeton.

\footnotetext{
${ }^{6}$ Site oficial: https://www.warnerbros.com/movies/where-wild-things-are/

${ }^{7}$ Para apontamentos e reflexões sobre o ato tradutório entre o português brasileiro e o chinês, recomenda-se a leitura de Sproviero (2006), Menezes e Chen Chen (2019) e Jatobá (2019).

${ }^{8}$ Aqui, a denominação Picture Book não será traduzida, objetivando a diferenciação entre ela e Illustrated Book (livro ilustrado). Os aspectos que distinguem esses dois tipos de livro infantil serão destacados na seção 3.1 .
}

TradTerm, São Paulo, v.37, n. 2, janeiro/2021, p. 563-595

Número Especial - Linguística de Corpus

www.revistas.usp.br/tradterm 
Filho de imigrantes judeus poloneses, sendo sua mãe costureira e seu pai contador de histórias, Sendak teve sua infância marcada por mortes de familiares durante o Holocausto. Iniciou sua carreira vendendo ilustrações para vitrines de lojas, jornais e revistas. Entre o fim da década de 1940 e a década de 1950, ilustrou mais de 30 livros escritos por outros autores, como Atomics for the Millions (1947) ${ }^{9}$, de Dr. Maxwell Leigh Eidinoff e Little Bear $(1957)^{10}$, de Else Holmelund Minarik. Em 1956, Sendak estreou como autor e ilustrador com o livro Kenny's Window, porém, apenas em 1963, com a publicação de Where the Wild Things Are, tornou-se um autor prestigiado.

Figura 1: Capa do livro Where the Wild Things Are, escrito por Maurice Sendak

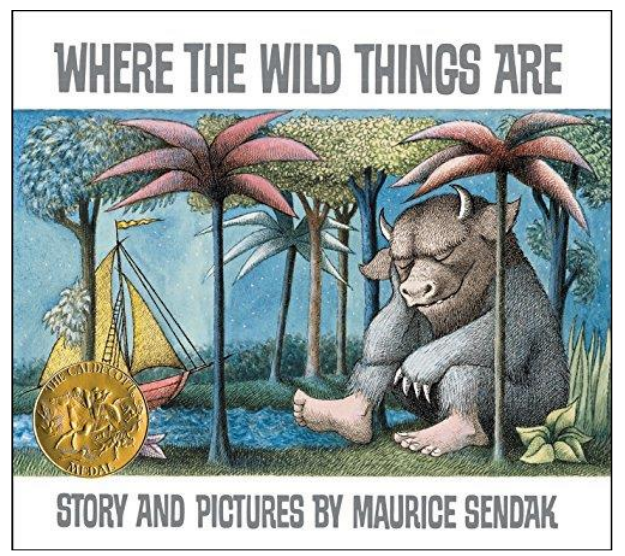

Com mais de 19 milhões de cópias vendidas, Where the Wild Things Are conta a aventura de Max, um garoto fantasiado de lobo, que é mandado para o quarto sem jantar por causa de seu mau comportamento. Já no castigo, as paredes do seu quarto começam a transformar-se em árvores e ele se vê no meio de uma floresta. De repente, Max está em um barco, no oceano, navegando para onde vivem as coisas selvagens. Lá, torna-se rei e ordena que a selvageria comece, fazendo com que as coisas selvagens rujam, brinquem e dancem, mas, repentinamente, ordena que parem a diversão e as manda para a cama sem jantar. Ele começa a sentir-se sozinho e decide voltar para o

\footnotetext{
${ }^{9}$ Primeiro livro ilustrado por Maurice Sendak.

${ }^{10} \mathrm{Na}$ adaptação televisiva transmitida para mais de 5 países, incluindo o Brasil, Sendak atuou como produtor executivo.

TradTerm, São Paulo, v.37, n. 2, janeiro/2021, p. 563-595

Número Especial - Linguística de Corpus

www.revistas.usp.br/tradterm
} 
lugar onde alguém o ama. Então, Max navega de volta para seu quarto, onde encontra seu jantar ainda quente.

Ainda que tenha um enredo aparentemente simples, o livro causou alvoroço, conforme relata Lanes (1984: 104):

O livro foi publicado no outono de 1963 sem nenhum alarde especial da Harper. Somente quando ele leu as primeiras cartas negativas de bibliotecários e pais preocupados foi que Sendak percebeu que havia escrito um trabalho controverso. (...) Há muito tempo reconhecido como um artista altamente talentoso e sério, ele agora fornecia às crianças um livro inquestionavelmente bonito, mas bem - assustador. Max fica realmente bravo com sua mãe e foge para um sonho/fantasia que contém coisas selvagens possivelmente aterrorizantes. Muitos pais, educadores e bibliotecários ficaram confusos, e vários guardiões do estilo da inocência infantil começaram a fazer perguntas: 0 livro incomodaria as crianças pequenas? O mau comportamento de Max convidaria jovens ouvintes-visualizadores a imitá-lo? As coisas selvagens induziriam pesadelos nas crianças ou seriam psicologicamente prejudiciais de outras maneiras? ${ }^{11}$

Em 1964, Sendak expôs sua percepção como autor em seu discurso de premiação da medalha Caldecott:

(...) o que é tão óbvio quanto [a tentativa de evitar a exposição prematura a experiências dolorosas] - e o que muitas vezes é esquecido - é o fato de que, desde os primeiros anos, as crianças se familiarizam com emoções perturbadoras, que 0 medo e a ansiedade são uma parte intrínseca de suas vidas cotidianas, que lidam continuamente com a frustração da melhor maneira possível. E é através da fantasia que as crianças atingem a catarse. É o melhor meio que elas têm para domesticar as Coisas Selvagens. (LANES 1984: 107) ${ }^{12}$

Apesar das controversas não solucionadas, Where The Wild Things Are tornou-se um "sucesso sem precedentes", sendo traduzido para diversas

\footnotetext{
${ }^{11}$ Citação original: "The book was published in the fall of 1963 with no special fanfare from Harper. It was only when he read the first negative letters from troubled librarians and parents that Sendak realized he had written a controversial work. (...) Long recognized as a highly talented and serious artist, he had now provided children with an unquestionably beautiful but-well-scary picture book. Max gets truly angry with his mother and escapes into a dream/ fantasy containing possibly terrifying wild things. Many parents, educators, and librarians were confounded, and several self-styled guardians of childhood innocence began asking questions: Would the book upset small children? Would Max's bad behavior invite young listener-viewers to emulate him? Would the wild things induce nightmares in children or be psychologically harmful in other ways?"

${ }^{12}$ Citação original completa: “(...)But what is just as obvious-and what is too often overlooked-is the fact that from their earliest years children live on familiar terms with disrupting emotions, that fear and anxiety are an intrinsic part of their everyday lives, that they continually cope with frustration as best they can. And it is through fantasy that children achieve catharsis. It is the best means they have for taming Wild Things.(...)"
}

TradTerm, São Paulo, v.37, n. 2, janeiro/2021, p. 563-595

Número Especial - Linguística de Corpus

www.revistas.usp.br/tradterm 
línguas estrangeiras, como dinamarquês, galês e até mesmo latim, em uma edição não oficial dos alunos do Mamaroneck High School, em 1972 (LANES 1984: 106).

Com relação às vendas da obra, a autora exemplifica:

Em sua edição de capa dura, Where the Wild Things Are já vendeu mais de 700.000 cópias até a data de redação deste documento [1980] e, em cada período de seis meses de royalties, este primeiro e ainda mais popular dos picture books de Sendak, vende, em média, de 15.000 a 16.000 cópias. Uma versão em brochura vendida apenas no mercado escolar vendeu mais 1.800 .000 cópias. (LANES 1984: $106)^{13}$

Reiterando a aceitação da obra entre o público infantil e adulto, Philip Nel, no volume da revista PMLA que homenageia Sendak, afirmou que os trabalhos do autor são respondidos emocionalmente pelos leitores porque, enquanto os adultos "preferem ver a infância representada como um local seguro", Sendak aborda a "vulnerabilidade inerente às crianças", aspecto conhecido pelos jovens leitores (NEL 2014: 114).

Quanto às ilustrações monstruosas e o enredo do livro, Cech (2014: 105) relata que ao questionar o que era um livro infantil e seu conteúdo, Sendak, pressagiou as mudanças culturais estadunidenses que ocorreram na década de 1960. Segundo ele, atualmente, 'wild things' tornou-se um epíteto incorporado na cultura popular - músicas, filmes, novelas, títulos de revistas e jornais - "referindo-se não somente, à fauna e flora selvagem, mas também a tudo que é imprevisível, impulsivo".

\subsection{Wild Things no Brasil e na China}

Ainda que a tradução no Brasil ${ }^{14}$ remonte ao passado colonial, mostrando-se presente a partir do século XVI com a necessidade de intérpretes, apenas no final do século XVIII, com a reforma educacional

\footnotetext{
${ }^{13}$ Citação original: "In its hard-cover edition, Where the Wild Things Are has sold more than 700,000 copies as of this writing, and, in each six-month royalty period, this first and still most popular of Sendak's picture books sells an average of 15,000-16,000 copies. A paperback version sold only in the school market has sold an additional 1,800,000 copies."

${ }^{14}$ Para informações aprofundadas sobre a História da tradução e interpretação no Brasil, recomenda-se: Barbosa e Wyler (1998) e Silva-Reis e Milton (2016).
}

TradTerm, São Paulo, v.37, n. 2, janeiro/2021, p. 563-595

Número Especial - Linguística de Corpus

www.revistas.usp.br/tradterm 
implementada pelo Marquês de Pombal, textos não catequizadores chegaram às mãos de um seleto público formado pelos adolescentes da elite cultural. Seguindo as diretrizes impostas por Pombal, o ensino deixou de ser religioso e, pela primeira vez no país, as escolas tinham aulas régias com conteúdos que iam de gramática latina à leitura, cálculo e filosofia. Para tanto, muitos dos livros-didáticos eram traduzidos em Portugal e de lá vinham para o Brasil (SILVA-ReIS E MiLton, 2016:14).

Especificamente no que se refere à literatura voltada para os públicos infantil e juvenil, as primeiras traduções de obras estrangeiras não didáticas que chegaram ao Brasil datam do século XIX, também provindas de Portugal e, de acordo com Zilberman e Lajolo (1993: 19), a escola era "a destinatária prevista para estes livros, que nela circulam como leitura subsidiária ou como prêmio para os melhores alunos". Ao longo dos anos, com a miscigenação e a mudança linguística no território brasileiro, predominantemente influenciada por índios e negros, o português europeu tornou-se de difícil entendimento e livros retraduzidos para a língua local fizeram-se necessários. (COELHO 2000: 148; RocHA 2017: 1-5). Já na segunda metade do século XIX, estudiosos como Carlos Jansen Muller e Figueiredo Pimentel dispenderam esforços para adaptar/traduzir algumas obras estrangeiras da literatura infantil como As mil e umas noites (1882), As viagens de Gulliver (1888) e Contos da Carochinha (1894) (RocHA 2017: 2-3).

Ainda que tenham tentando realizar traduções mais acessíveis para o público infanto-juvenil, com linguagem menos castiça, Monteiro Lobato considerava essas adaptações muito cultas, sugerindo que versões mais "abrasileiradas" fossem escritas (RocHA 2017 : 3). Nas primeiras décadas do século XX, Lobato entra em cena como autor e tradutor, sendo considerado como o marco histórico da atividade tradutória, conforme explicitado:

O escritor Monteiro Lobato ao iniciar a sua atividade escrita para crianças, na década de 1920, inicia também o exercício tradutório para este público e traz para o cenário brasileiro a tradução de Alice no país das Maravilhas, de Lewis Carrol, Pinóquio, de Collodi entre outros títulos que até então circulavam somente na língua mãe. (DEBUS e TORRES 2015:11)

TradTerm, São Paulo, v.37, n. 2, janeiro/2021, p. 563-595 Número Especial - Linguística de Corpus www.revistas.usp.br/tradterm 
Atualmente, com o desenvolvimento constante de tecnologias que propõe o contato entre países e culturas, muitas das traduções literárias infantis brasileiras encontram-se diretamente relacionadas ao âmbito comercial das adaptações: filmes, peças, jogos, brinquedos, parques de diversão e roupas são alguns dos subprodutos provindos da literatura. Com a obra de Sendak não foi diferente.

Traduzido para o português brasileiro por Heloisa Jahn, Onde vivem os monstros foi publicado pela editora Cosac Naify em 2009, junto ao lançamento da adaptação cinematográfica de Where the Wild Things Are ${ }^{15}$. Ressalta-se que, até o presente momento, essa é a única tradução disponível da obra nesse idioma. Em 2014, logo após o aniversário de 50 anos da obra original, a editora publicou uma segunda edição do livro traduzido, respeitando o novo Acordo Ortográfico da Língua Portuguesa. No que se refere à tradutora e sua experiência na área, de acordo com o Dicionário de Tradutores do Brasil ${ }^{16}$, Jahn traduziu mais de 100 títulos, sendo mais da metade deles no segmento de literatura infanto-juvenil. São exemplos: Histórias maravilhosas de Andersen (1995), Rima pra cá, rima pra lá (2002) e Você conhece a Píppi Meialonga? (2016).

Diferentemente do Brasil, as traduções de livros estrangeiros na China e em Taiwan ocorreram expressivamente devido ao esforço em aprimorar a aprendizagem da língua, como exemplificado por Bradbury e Liu (apud YANG; YANG 2011: 19) ao afirmarem que a Mandarin Daily News Association ${ }^{17}$ traduziu uma série de livros vencedores do prêmio Caldecott para “desenvolver o letramento e popularizar o Mandarim ou Chinês desde meados dos anos 60"18.

Em Taiwan, pais e educadores têm predileção pelos picture books por considerá-los um recurso importante no desenvolvimento da proficiência em chinês, sendo esse o material de leitura mais utilizado na infância. Além disso,

${ }^{15}$ Também em 2009 o jogo de vídeogame de mesmo título foi lançado pela Warner Bros. Interactive Entertainment para diversas plataformas: https://youtu.be/WhereTheWildGame

${ }^{16}$ Disponível em: https://dicionariodetradutores.ufsc.br/pt/HeloisaJahn.htm

${ }^{17}$ Associação responsável pelo tradicional jornal infantil Mandarin Daily News (disponível em: www.mdnkids) e também pelo Mandarin Daily News Language Center.

${ }_{18}$ Citação original: "to develop children's literacy and to popularize Mandarin or Chinese since the mid-sixties".

TradTerm, São Paulo, v.37, n. 2, janeiro/2021, p. 563-595

Número Especial - Linguística de Corpus

www.revistas.usp.br/tradterm 
os picture books traduzidos são mais atrativos para editores do que os escritos originalmente em chinês, pois o custo de publicação é menor e o número de cópias impressas em cada tiragem, maior (YANG; YANG 2011: 18).

Sobre as traduções na China continental, Wah e Ho (2005: 821) relatam que após a quebra da tradição literária confuciana, junto à Primeira Guerra Mundial e à Revolução Chinesa, a sociedade chinesa passou a admirar realizações ocidentais:

Nunca antes na história da China os autores chineses foram tão expostos a uma cultura alheia à deles. À medida que as traduções das obras literárias ocidentais se tornaram moda na China, as primeiras obras da literatura infantil publicadas na virada do século $\mathrm{XX}$ foram, principalmente, obras ocidentais traduzidas. As mais populares entre elas foram As Fábulas de Esopo, Os Contos de Grimm e Andersen e As [mil e uma] Noites nas Arábias. O termo Tong-hua (histórias infantis) foi utilizado pela primeira vez. ${ }^{19}$

A primeira tradução de Where the Wild Things Are para o chinês tradicional de que se tem conhecimento foi publicada em Taiwan pela editora Yīngwén hànshēng chūbăn shè 英文漢聲出版社, em 1987, com o título Yěshòu guó 野獸國 - tradução literal: 0 país das feras.

A tradução aqui estudada é a em chinês simplificado, publicada em 2009 pela editora Tsai Fong Books e intitulada Yěshòu chūmò de dífāng 野兽出 没的地方 - tradução literal: O lugar onde a fera aparece e desaparece traduzida por Ājiǎ 阿甲, pseudônimo de Lín Xiǎoxī 林晓琋.

Assim como Heloisa Jahn, Ājiă 阿甲 apresenta uma carreira consolidada na tradução de literatura infantil. Autor e tradutor de livros infantis, é conhecido por ser o co-fundador de um grupo de leitura e por ter traduzido mais de 90 títulos infantis originários da Inglaterra e dos Estados Unidos. São exemplos: Shítou tāng 石头汤 (20013), Stone Soup; Yóngqì 勇气 (2018),

\footnotetext{
${ }^{19}$ Citação original: "Never before in China's history were Chinese authors exposed so much to a culture alien to them. As translations of Western literary works became fashionable in China, the earliest works of children's literature at the turn of the twentieth century were mostly translated works from the West. Most popular among these translated works were Aesop's Fables, the fairy tales of the Grimms and Andersen, and The Arabian Nights. The term Tonghua (children's tales) was coined for the first time."
}

TradTerm, São Paulo, v.37, n. 2, janeiro/2021, p. 563-595

Número Especial - Linguística de Corpus

www.revistas.usp.br/tradterm 
Courage e Bìdé tù de shijiè 比得兔的世界 (2011-2018), The Tale of Peter Rabbit.

\section{Pressupostos teóricos}

Conforme explicado anteriormente, o corpus desta pesquisa é formado por um livro infantil e suas traduções. Sendo assim, propõe-se uma breve explanação sobre Literatura Infantil e seus aspectos constituintes e tradutórios, bem como sobre as estratégias tradutológicas que serão referidas no decorrer da análise.

\subsection{Literatura Infantil, picture books e tradução}

De acordo com Williams e Chesterman (2002: 12), a definição sobre o que é literatura infantil é complexa, vaga e dificultosa. Muitos, inclusive a crítica, entendem esse gênero como secundário. Sobre a visão da crítica, Peter Hunt ironiza ao dizer que "a literatura infantil parece ser um campo de estudo atraente", uma vez que "os livros infantis têm estado despercebidos dos gurus intelectuais e culturais, eles são (aparentemente) maravilhosamente livres dos 'deveres': o que devemos pensar e dizer sobre eles”, enfatizando, ainda, que a literatura infantil talvez seja literatura real - "se 'literatura' consiste em textos que envolvem, mudam e provocam respostas intensas nos leitores" (HUNT 2005: 1) ${ }^{20}$.

Em verdade, esse tipo de literatura é uma criação valorosa, conforme destaca Coelho (1987: 10-12) ao afirmar que "A Literatura Infantil é, antes de tudo, literatura; ou melhor, é arte: fenômeno de criatividade que representa o Mundo, o Homem, a Vida através da palavra.". Em consonância com a afirmação de ser arte, a literatura infantil é apresentada aos pequenos

\footnotetext{
${ }^{20}$ Citação original completa: “'Children's literature' sounds like an enticing field of study; because children's books have been largely beneath the notice of intellectual and cultural gurus, they are (apparently) blissfully free of the 'oughts': what we ought to think and say about them. More than that, to many readers, children's books are a matter of private delight, which means, perhaps, that they are real literature - if 'literature' consists of texts which engage, change, and provoke intense responses in readers."
}

TradTerm, São Paulo, v.37, n. 2, janeiro/2021, p. 563-595

Número Especial - Linguística de Corpus

www.revistas.usp.br/tradterm 
leitores nos mais variados formatos - livros de papel, plástico, tecido, pop-up, picture books ${ }^{21}$, entre outros.

Ao utilizar simbolismos para explorar o mundo sentimental das crianças, Sendak tornou-se um dos nomes de referência dos picture books. Porém, a diferença entre esse formato de literatura e os livros ilustrados nem sempre é bem definida. De acordo com o Dicionário Histórico da Literatura Infantil, tradicionalmente, as figuras dos livros ilustrados baseiam-se no texto verbal preexistente e, por isso, desempenham papel subserviente a ele, enquanto que, nos picture books, "as imagens são tão importantes quanto as palavras, e sua relação sinérgica significa que o efeito total depende não apenas da união dos elementos visuais e verbais, mas também da interação entre eles." (O'Sullivan 2010: 198) ${ }^{22}$. Picture book é um "formato nele mesmo" em que figuras são necessárias para preencher as lacunas deixadas pelas palavras e vice-versa, havendo uma "parceria de igual e total interdependência", o que também afeta o fazer tradutório (LANES 1984: 85).

Também refletindo sobre o fazer tradutório, Azenha (2015: 218 - 219) aponta que a literatura infantil não deve ser entendida como "objeto facilitado", já que é constituída por aspectos plurais, interligados às mais diversas áreas do saber, sendo essa interconexão o maior desafio no exercício tradutológico. Contudo, não somente a própria literatura infantil se torna um desafio para o tradutor, como também a recepção de sua tradução: ao traduzir literatura infantil, o tradutor tem em mente seu público-alvo - o leitor infantil, e também a aceitação de pais, professores, bibliotecários e editores (PASCUA-Febles 2006: 111).

No que diz respeito especificamente aos aspectos da tradução de picture books, Oittinem, Ketola e Garavini (2018: 96) afirmam:

Os tradutores de picture books devem estar cientes dos diferentes potenciais de expressão, como tom, entonação, andamento e pausas, e contribuir de todas as formas possíveis para a apreciação da história pelo leitor em voz alta, o que, por sua vez, contribui

\footnotetext{
${ }^{21}$ Não há consenso quanto à grafia de picture books, a qual também pode ser encontrada como picturebooks e picture-books.

${ }^{22}$ Citação original: "In picture books, on the other hand, the pictures are as important as the words, and their synergetic relationship means that the total effect depends not only on the union of the visual and the verbal elements but also on the interaction between them."
}

TradTerm, São Paulo, v.37, n. 2, janeiro/2021, p. 563-595

Número Especial - Linguística de Corpus

www.revistas.usp.br/tradterm 
para a apreciação da história pelo leitor infantil. Antes de começar uma tradução, o tradutor deve estudar cuidadosamente o ritmo da obra original, lendo em voz alta para captar o ritmo, a entonação e o tom da história. ${ }^{23}$

Com as características da obra e dificuldades tradutológicas já esclarecidas, apresentaremos, a seguir, as considerações de Schleiermacher e Venuti sobre tradução para que, posteriormente, se compreendam as estratégias que foram utilizadas pelos tradutores.

\subsection{As estratégias tradutológicas}

No texto Sobre os diferentes métodos de traduzir, Schleirmacher (2017: 242) expôs seus apontamentos sobre tradução e métodos, dizendo que "Ou bem o tradutor deixa o escritor o mais tranquilo possível e faz com que o leitor vá ao seu encontro, ou bem deixa o mais tranquilo possível o leitor e faz com que o escritor vá ao seu encontro.".

Ao levar o leitor até o escritor, o tradutor reproduziria a impressão que se teria ao ler a obra original. Enquanto que, ao levar o escritor até o leitor, o tradutor proporia a leitura "sem fadiga", sem estranheza, gerando a sensação de que o texto foi escrito na própria língua materna do leitor.

Baseando-se nos estudos de Schleiermacher, Venuti (1995: 16-20) acrescenta o componente ideológico e propõe a existência de dois tipos de estratégias tradutológicas: a domesticação e a estrangeirização. Segundo o autor, a tradução domesticadora aproxima o autor ao leitor por meio de uma redução etnocêntrica do texto estrangeiro, o que acarreta a aniquilação da alteridade do texto. Sendo assim, a tradução submete-se aos aspectos da cultura de chegada. Já a tradução estrangeirizadora propõe o caminho inverso: levar o leitor ao autor. Para tanto, há uma escolha ética, afasta-se das normas dominantes na cultura de chegada e respeitam-se as diferenças culturais.

${ }^{23}$ Citação original: "Translators of picture books should be aware of the different potentials of expression, such as tone, intonation, tempo, and pauses, and contribute in every way possible to the aloud-reader's enjoyment of the story, which, in turn, contributes to the child reader's enjoyment of the story. Before starting an actual translation, a translator should carefully study the rhythm of the original, reading it aloud to catch the rhythm, intonation, and tone of the story."

TradTerm, São Paulo, v.37, n. 2, janeiro/2021, p. 563-595

Número Especial - Linguística de Corpus

www.revistas.usp.br/tradterm 
Considerando a explanação acima, bem como os aspectos díspares que constituem os hábitos culturais e linguísticos do corpus de pesquisa em questão, no presente estudo serão apresentados exemplos do uso das estratégias de domesticação e estrangeirização na nomeação dos personagens. Os exemplos foram coletados com a aplicação da metodologia a ser elucidada.

\section{Metodologia}

A metodologia empregada na presente pesquisa é a da Linguística de Corpus que se dedica "à exploração da linguagem por meio de evidências empíricas, extraídas por computador" (BERBER SARDINHA 2004: 3). Essas evidências são extraídas de um corpus - "coletânea de textos, necessariamente em formato eletrônico, compilados e organizados segundo critérios ditados pelo objetivo de pesquisa a que se destina" (TAGNIN 2013: 29).

Com o modelo de comparação triangular, como demonstra a Figura 2, foram estudados corpora paralelos, isto é, original e respectivas traduções.

Figura 2: Texto original e suas traduções no modelo triangular de comparação.

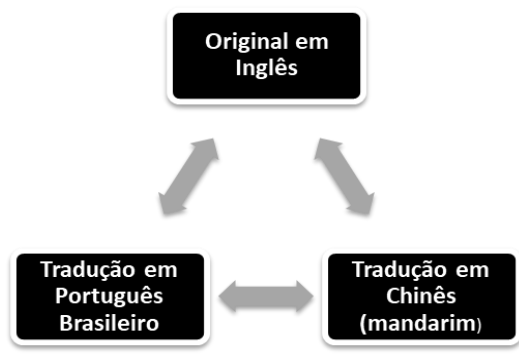

Porém, para que a análise fosse realizada, fizeram-se necessárias algumas etapas prévias:

\section{Coleta dos textos}

- Aquisição dos livros: foram comprados o livro original e suas traduções em português brasileiro e chinês;

- Digitação dos textos: por causa da curta extensão dos livros, optouse pela digitação dos três textos, em vez da digitalização;

- Revisão dos textos: a partir do que foi digitado, realizou-se uma revisão manual por meio de releitura;

TradTerm, São Paulo, v.37, n. 2, janeiro/2021, p. 563-595

Número Especial - Linguística de Corpus

www.revistas.usp.br/tradterm 
- Segmentação manual do corpus em chinês, pois o programa WordSmith Tools ${ }^{24}$ não identifica palavras não espaçadas, como é o caso dos ideogramas apresentados no idioma em questão;

- Inserção da tag <ca> no corpus em chinês para identificar palavras enfatizadas por fonte de tamanho maior;

- Transformação dos textos em arquivos de formato txt;

- Nomeação dos arquivos: para que ocorresse uma rápida identificação visual; os textos em inglês, português e chinês foram nomeados como WILD_THING_ING, WILD_THING_PTG E WILD_THING_CHN, respectivamente.

Com a coleta pronta, os textos passaram a compor corpora e, depois de transformados em formato $t x t$, puderam ser processados pelo programa de análise lexical WST que é composto por ferramentas variadas. A seguir serão explicitadas apenas as que foram aplicadas nesta pesquisa.

> WordSmith Tools e ferramentas de análise linguística

- Ferramenta WordList: fornece uma lista de palavras de cada texto, por ordem alfabética ou por ordem de frequência. Ademais, essa ferramenta fornece dados estatísticos sobre os textos selecionados (Fig. 3);

- Ferramenta Concord: apresenta as ocorrências da palavra de busca no corpus e permite maior contextualização por meio da ampliação da linha de concordância; (Fig. 4, 5, 6 e 7)

- Ferramenta Aligner: alinhador computacional multilíngue que auxilia na visualização dos corpora (Fig. 8, 9 e 10).

\section{Análise}

Visto que a presente pesquisa utiliza o direcionamento pelo corpus como abordagem, 0 passo inicial empregado para a análise foi 0 processamento dos corpora em estudo pela ferramenta Wordlist, que, além de gerar as listas de palavras, coleta e apresenta dados estatísticos de cada uma delas. A tabela a seguir traz alguns dos dados obtidos:

${ }^{24}$ Doravante WST.

TradTerm, São Paulo, v.37, n. 2, janeiro/2021, p. 563-595

Número Especial - Linguística de Corpus

www.revistas.usp.br/tradterm 
Tabela 1: Informações estatísticas extraídas pela ferramenta Wordlist

\begin{tabular}{lccc}
\hline & TOKENS & TYPES & TYPE/TOKEN RATIO \\
\hline WILD_THING_ING & 345 & 141 & 40,87 \\
WILD_THING_PTG & 345 & 165 & 47,83 \\
WILD_THING_CHN & 307 & 154 & 50,16 \\
\hline
\end{tabular}

As informações estatísticas revelam que, apesar de ser composta pelo menor número total de vocábulos (tokens), contando suas repetições - 307 e apresentar o valor médio, entre os três textos, de vocábulos não repetidos (types) - 154, a tradução em chinês é a que apresenta maior variedade lexical, conforme comprovado pelo type/token ratio de 50,16.

Em seguida, as três listas de palavras foram salvas individualmente e, então, comparadas. A figura abaixo apresenta as listas de palavras por frequência em inglês, português e chinês, respectivamente:

Figura 3: Wordlist de Where the Wild Things Are, Onde vivem os monstros e Yěshòu chūmò de difāng 野兽出没的地方, respectivamente.

\begin{tabular}{|c|c|c|c|c|c|c|c|c|c|c|c|c|c|c|c|}
\hline \multicolumn{3}{|c|}{ W Wordlist } & \multicolumn{4}{|c|}{$\sqrt{\omega}$ Wordlist } & \multicolumn{3}{|r|}{-} & \multicolumn{3}{|c|}{$\sqrt{w}$ Wordlist } & \multicolumn{3}{|c|}{$-\quad \square$} \\
\hline File Edit & View Compu & ite Setting & ngs $\underline{W}_{\text {ind }}$ & & File Edit & View Sompute & Seetting: & 75 Windo & ows $\underline{H}$ el & File É $\underline{\text { dit }}$ & View Somp & ute seett & tings $\underline{W}_{i}$ & indows & Help \\
\hline $\mathrm{N}$ & Word & Freq. & $\%$ & Texts & $\mathrm{N}$ & Word & Freq. & $\%$ & Texts & $\mathrm{N}$ & Word & Freq. & $\%$ & Texts & \\
\hline 1 & AND & 351 & 10,09 & 1 & 1 & $\mathrm{E}$ & 26 & 7,54 & 1 & 1 & 的 & 19 & 6,19 & 1 & 100,0 \\
\hline 2 & THE & 16 & 4,61 & 1 & 2 & $\mathrm{DE}$ & 16 & 4,64 & 1 & 2 & 他 & 14 & 4,56 & 1 & 100,0 \\
\hline 3 & WILD & 12 & 3,46 & 1 & 3 & MAX & 10 & 2,90 & 1 & 3 & 麦克斯 & 11 & 3,58 & 1 & 100,0 \\
\hline 4 & MAX & 10 & 2,88 & 1 & 4 & os & 10 & 2,90 & 1 & 4 & 可怕 & 8 & 2,61 & 1 & 100,0 \\
\hline 5 & OF & 10 & 2,88 & 1 & 5 & MONSTROS & 9 & 2,61 & 1 & 5 & 野兽 & 8 & 2,61 & 1 & 100,0 \\
\hline 6 & THEIR & 10 & 2,88 & 1 & 6 & TERRIVEIS & 8 & 2,32 & 1 & 6 & 了 & 7 & 2,28 & 1 & 100,0 \\
\hline 7 & THINGS & 10 & 2,88 & 1 & 7 & QUE & 7 & 2,03 & 1 & 7 & 它们 & 7 & 2,28 & 1 & 100,0 \\
\hline 8 & TERRIBLE & 8 & 2,31 & 1 & 8 & 0 & 6 & 1,74 & 1 & 8 & 不 & 6 & 1,95 & 1 & 100,0 \\
\hline 9 & ALL & 7 & 2,02 & 1 & 9 & SEUS & 6 & 1,74 & 1 & 9 & 出 & 5 & 1,63 & 1 & 100,0 \\
\hline 10 & $\mathrm{HE}$ & 6 & 1,73 & 1 & 10 & ELE & 5 & 1,45 & 1 & 10 & 地方 & 5 & 1,63 & 1 & 100,0 \\
\hline 11 & HIS & 6 & 1,73 & 1 & 11 & ONDE & 5 & 1,45 & 1 & 11 & 过 & 5 & 1,63 & 1 & 100,0 \\
\hline 12 & TO & 6 & 1,73 & 1 & 12 & PARA & 5 & 1,45 & 1 & 12 & 一 & 5 & 1,63 & 1 & 100,0 \\
\hline 13 & WHERE & 6 & 1,73 & 1 & 13 & UM & 5 & 1,45 & 1 & 13 & 吃 & 4 & 1,30 & 1 & 100,0 \\
\hline 14 & A & 5 & 1,44 & 1 & 14 & A & 4 & 1,16 & 1 & 14 & 你 & 4 & 1,30 & 1 & 100,0 \\
\hline 15 & HIM & 5 & 1,44 & 1 & 15 & COM & 4 & 1,16 & 1 & 15 & 去 & 4 & 1,30 & 1 & 100,0 \\
\hline 16 & ARE & 4 & 1,15 & 1 & 16 & DISSE & 4 & 1,16 & 1 & 16 & 出没 & 3 & 0,98 & 1 & 100,0 \\
\hline 17 & NIGHT & 4 & 1,15 & 1 & 17 & NO & 4 & 1,16 & 1 & 17 & ㅁ.4 & 3 & 0,98 & 1 & 100,0 \\
\hline 18 & SAID & 4 & 1,15 & 1 & 18 & NOITE & 4 & 1,16 & 1 & 18 & 却 & 3 & 0,98 & 1 & 100,0 \\
\hline 19 & EAT & 3 & 0,86 & 1 & 19 & POR & 4 & 1,16 & 1 & 19 & 晚饭 & 3 & 0,98 & 1 & 100,0 \\
\hline 20 & EYES & 3 & 0,86 & 1 & 20 & SEMANA & 4 & 1,16 & 1 & 20 & 晚上 & 3 & 0,98 & 1 & 100,0 \\
\hline 21 & GREW & 3 & 0,86 & 1 & 21 & TODOS & 4 & 1,16 & 1 & 21 & 王 & 3 & 0,98 & 1 & 100,0 \\
\hline 22 & IN & 3 & 0,86 & 1 & 22 & VIVEM & 4 & 1,16 & 1 & 22 & 要 & 3 & 0,98 & 1 & 100,0 \\
\hline 23 & INTO & 3 & 0,86 & 1 & 23 & COMER & 3 & 0,87 & 1 & 23 & 野兽们 & 3 & 0,98 & 1 & 100,0 \\
\hline 24 & KING & 3 & 0,86 & 1 & 24 & DELE & 3 & 0,87 & 1 & 24 & 长 & 3 & 0,98 & 1 & 100,0 \\
\hline 25 & so & 3 & 0,86 & 1 & 25 & ELES & 3 & 0,87 & 1 & 25 & 最 & 3 & 0,98 & 1 & 100,0 \\
\hline 26 & UP & 3 & 0,86 & 1 & 26 & INTEIRO & 3 & 0,87 & 1 & 26 & 爱 & 2 & 0,65 & 1 & 100,0 \\
\hline$<$ & & & & & $<$ & & & & & $<>$ & & & & & $>$ \\
\hline frequency & | alphabetical & statistics & filenames & note & frequency & | alphabetical st & atistios $f$ & filenames & notes & frequency & alphabetical & statistics & s filenam & nes no & \\
\hline 141 entries & Row 37 & & & & 165 entries & S Row 33 & & & & 154 entries & $5 \quad$ Row 31 & & & & \\
\hline
\end{tabular}

Em uma análise comparativa entre as três listas de palavras, a informação que mais nos chamou a atenção foi o nome do personagem principal, Max, que foi mantido no português brasileiro e também no chinês

TradTerm, São Paulo, v.37, n. 2, janeiro/2021, p. 563-595

Número Especial - Linguística de Corpus

www.revistas.usp.br/tradterm 
ao ser traduzido foneticamente ${ }^{25}$ - Màikès̄̄ 麦克斯. Segundo as estratégias tradutológicas propostas por Venuti, ambos os tradutores aplicaram a estratégia de estrangeirização, já que tanto no Brasil quanto na China esse nome não é considerado comum.

Outra semelhança apontada refere-se ao uso do adjetivo que descreve os olhos, dentes, garras e rugidos das wild things. Conforme demonstra a Figura 3, o adjetivo 'terrible' foi traduzido como 'terríveis' em português brasileiro e como 'kěpà 可怕' em chinês que, segundo o aplicativo Pleco ${ }^{26}$, significa terrifying, ou seja, amedrontador, assustador (linhas 8, 6 e 4, respectivamente). Tanto no texto original quanto nas traduções, o adjetivo em questão foi utilizado 8 vezes, o que indica uma possível aproximação entre as traduções.

Aponta-se, também, a disparidade na frequência de uso dos vocábulos 'things' - linha 7, 10 vezes -, e suas traduções para o português brasileiro e para o chinês - 'monstros' (linha 5, 9 vezes) e ‘yěshòumen 野兽们' (linha 23, 3 vezes), respectivamente. Ademais, as linhas 5 e 23 da terceira coluna, 'yěshòu 野兽'e 'yěshòumen 野兽们', indicam uma possível alternância na tradução do vocábulo 'things'. A partir dessas observações, propôs-se um estudo das linhas de concordância que apresentam esses termos e, para tanto, a ferramenta Concord foi utilizada.

\footnotetext{
${ }^{25} \mathrm{Na}$ China é comum traduzir nomes estrangeiros usando a conversão fonética, contudo, os resultados são percebidos com estranheza pelos nativos, já que, frequentemente, os nomes convertidos não apresentam significado ou são compostos por mais de 2 ideogramas, o que, lá, é incomum.

${ }^{26}$ Dada a impossibilidade de encontrar todas as entradas analisadas em dicionário do par chinês-português, optamos por usar como aporte o dicionário Oxford Chinese Dictionary (2010), licenciado pelo aplicativo Pleco. Sendo assim, o inglês foi utilizado como língua intermediária.
}

TradTerm, São Paulo, v.37, n. 2, janeiro/2021, p. 563-595

Número Especial - Linguística de Corpus

www.revistas.usp.br/tradterm 
Figura 4: Linhas de concordância obtidas a partir da busca por 'things' em Where the Wild Things Are.

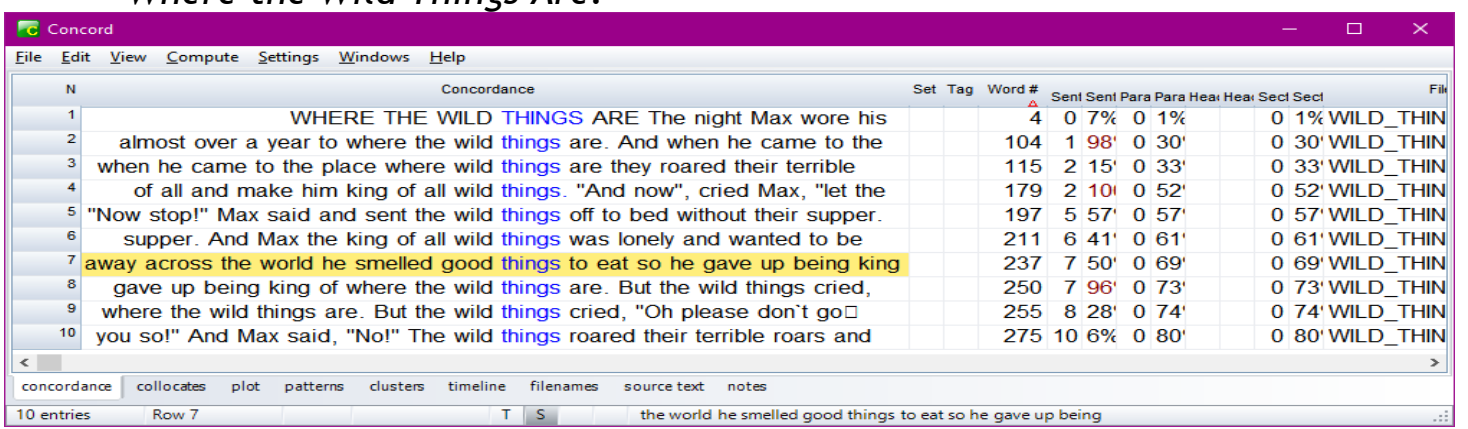

O vocábulo 'things' foi apresentado 10 vezes em todo o texto original, porém, na linha 7, em destaque, seu uso não é referente aos personagens, 'wild things', mas sim a produtos alimentícios, como é possível constatar pela própria linha de concordância, 'good things to eat' (coisas boas para comer). 0 mesmo não ocorre nos textos traduzidos.

Figura 5: Linhas de concordância obtidas a partir da busca por 'monstros' em Onde vivem os monstros.

\begin{tabular}{|c|c|c|c|c|c|c|c|c|}
\hline \multicolumn{6}{|c|}{ C Concord } & \multicolumn{2}{|c|}{$-\quad \square$} & \\
\hline \multicolumn{9}{|c|}{ File Edit View Compute Settings Windows Help } \\
\hline $\mathrm{N}$ & Concordance & Set Tag & Word\# & Sent Sent Pa & ara Para & & & \\
\hline 1 & ONDE VIVEM OS MONSTROS Na noite em que Max & & 4 & $07 \% 0$ & $01 \%$ & 0 & $1 \%$ WILD & THIN \\
\hline 2 & quase um ano para onde vivem os monstros. $E$ quando ele chegou aonde & & 105 & 11010 & $030^{\prime}$ & 0 & 30 WILD & THIN \\
\hline 3 & E quando ele chegou aonde vivem os monstros eles rugiram seus terriveis & & 113 & 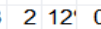 & $033^{\prime}$ & 03 & 33' WILD & THIN \\
\hline 4 & não havia e o fizeram rei de todos os monstros. "Agora", exclamou Max, & & 180 & 21010 & 052 & & $52^{\prime}$ WILD & THIN \\
\hline 5 & parem!", disse Max e mandou os monstros para a cama sem jantar. $\mathrm{E}$ & & 197 & 464 & 057 & & $57 \cdot$ WILD & THIN \\
\hline 6 & sem jantar. E Max, o rei de todos os monstros, ficou sozinho com vontade & & 210 & 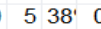 & 061 & & 61'WILD & THIN \\
\hline 7 & de ser rei do lugar onde vivem os monstros. Mas os monstros gritaram: & & 257 & 61010 & 074 & 0 & 74. WILD & THIN \\
\hline 8 & lugar onde vivem os monstros. Mas os monstros gritaram: "Oh, por favor não & & 260 & 722 & $075^{\prime}$ & 07 & 75' WILD_ & THIN \\
\hline 9 & de você!". E Max disse: "Não!". Os monstros rugiram seus terriveis rugidos & & 280 & $94 \% 0$ & 081 & 0 & 81' WILD & THIN \\
\hline \multicolumn{9}{|c|}{${ }^{2}$} \\
\hline \multicolumn{9}{|c|}{\begin{tabular}{|l|lllll} 
concordance & collocates plot patterns clusters timeline filenames source text notes
\end{tabular}} \\
\hline \multicolumn{9}{|l|}{9 entries } \\
\hline
\end{tabular}

Figura 6: Linhas de concordância obtidas a partir da busca por 'yěshòumen 野 兽们’ em Yěshòu chūmò de difāng 野兽出没的地方.

\begin{tabular}{|c|c|c|c|c|}
\hline \multicolumn{3}{|l|}{ C Concord } & \multirow[t]{2}{*}{-} & \multirow[t]{2}{*}{$\square$} \\
\hline File Edit View Compute Settings Windows Help & & & & \\
\hline Concordance & Set Tag & Word \# Sent Sent Para Para & Sectsect & Fill \\
\hline 开始了! " "停！" 麦克斯 说道。他 让 野兽们 去 睡觉, 不 给 它们 吃 晚饭。 & & $183836^{\prime} \quad 057^{\prime}$ & $057^{\prime}$ & WILD_THIN \\
\hline 2 决定 不 再 当 这个 地方 的 国 王。可是 野兽们 哭 喊着: “舆, 请 不 要 去一 & & $2321114^{\prime} \quad 0 \quad 72^{\prime}$ & $072^{\prime}$ & WILD_THIN \\
\hline 3 我们 太爱 你了! ”麦克斯 却 说: “不! ”野兽们 发出 可怕 的 吼声 露出 可怕的 & & $255136 \% \quad 0 \quad 80^{\prime}$ & $080^{\prime}$ & WILD_THIN \\
\hline 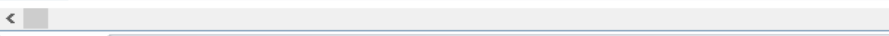 & & & & $>$ \\
\hline filenames source text notes & & & & \\
\hline
\end{tabular}

A Figura 5 apresenta as 9 entradas de linhas de concordância geradas a partir do texto em português brasileiro. Nela, observou-se que a única linha faltante é a que apresentaria a sentença traduzida de 'good things to eat'.

TradTerm, São Paulo, v.37, n. 2, janeiro/2021, p. 563-595

Número Especial - Linguística de Corpus

www.revistas.usp.br/tradterm 
Com a Figura 6 é possível constatar que as 3 entradas encontradas apresentam verbos de ação em suas colocações à direita: 'qù 去', go to, ir; ‘kū 哭', to cry, chorar e 'fāchū 发出', send out, com o sentido de mostrar, demonstrar. No entanto, nenhuma das entradas refere-se a alimentos e, de acordo com a Wordlist (Figura 2, linha 5), outras 8 entradas de linhas de concordância a partir de 'yěshòu 野兽', no singular, eram previstas.

Figura 7: Linhas de concordância obtidas a partir da busca por 'yěshòu 野兽' em Yěshòu chūmò de difāng 野兽出没的地方.

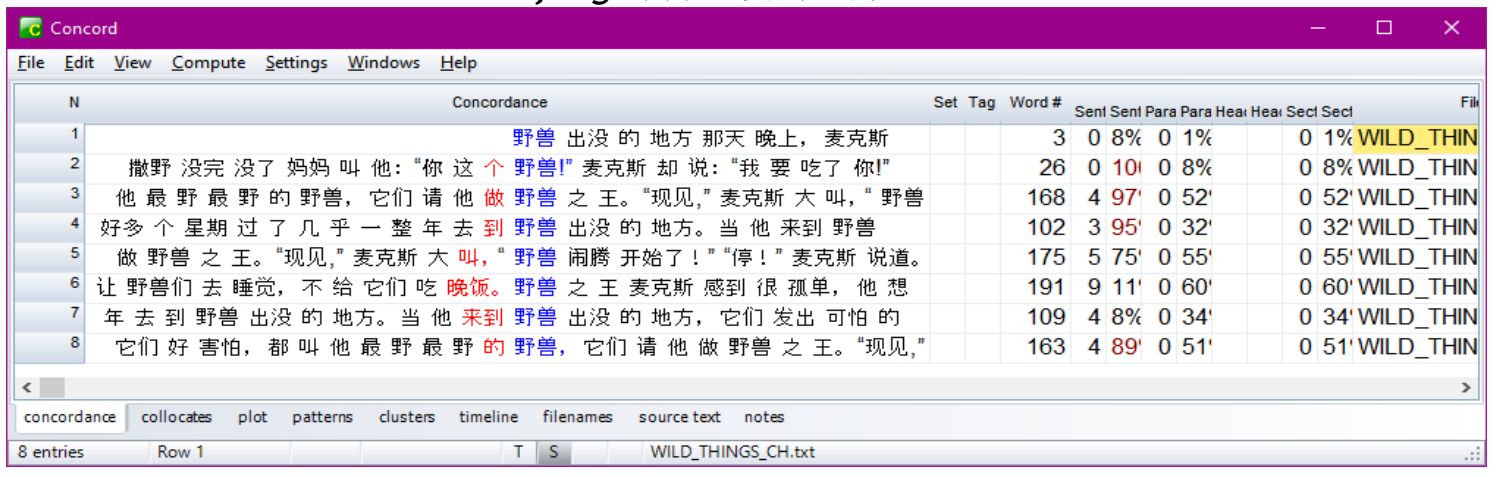

A Figura 7, por sua vez, ainda que não apresente a tradução para a sentença referente aos produtos alimentícios, afirma a tradução alternada do vocábulo 'things' entre 'yěshòu 野兽' e ‘yěshòumen 野兽们’. De fato, apesar de ser possível flexionar o substantivo em número na língua chinesa com o uso da partícula men 们, o tradutor manteve o vocábulo no singular na maior parte das entradas. Em continuidade, a fim de verificar as traduções propostas de 'good things to eat' e também buscar outros aspectos da obra e suas traduções, foi utilizada a ferramenta Aligner para realizar o alinhamento semiautomático dos corpora em estudo.

Com os arquivos salvos em formato .txt, o software realiza alinhamento automático dos textos, porém, a revisão manual do mesmo é necessária para que sejam corrigidos eventuais erros de distribuição de sentenças e parágrafos: aqui, foram consideradas sentenças cada linha escrita nas páginas dos livros, seja ela pontuada ou não e, como parágrafo, o bloco de sentenças presentes em cada página.

TradTerm, São Paulo, v.37, n. 2, janeiro/2021, p. 563-595

Número Especial - Linguística de Corpus www.revistas.usp.br/tradterm 
Após a revisão manual do alinhamento por pares, os corpora foram alinhados na configuração trilíngue (Fig. 8 e 9).

Figura 8: Alinhamento trilíngue revisado das primeiras 8 sentenças inglês/português/chinês.

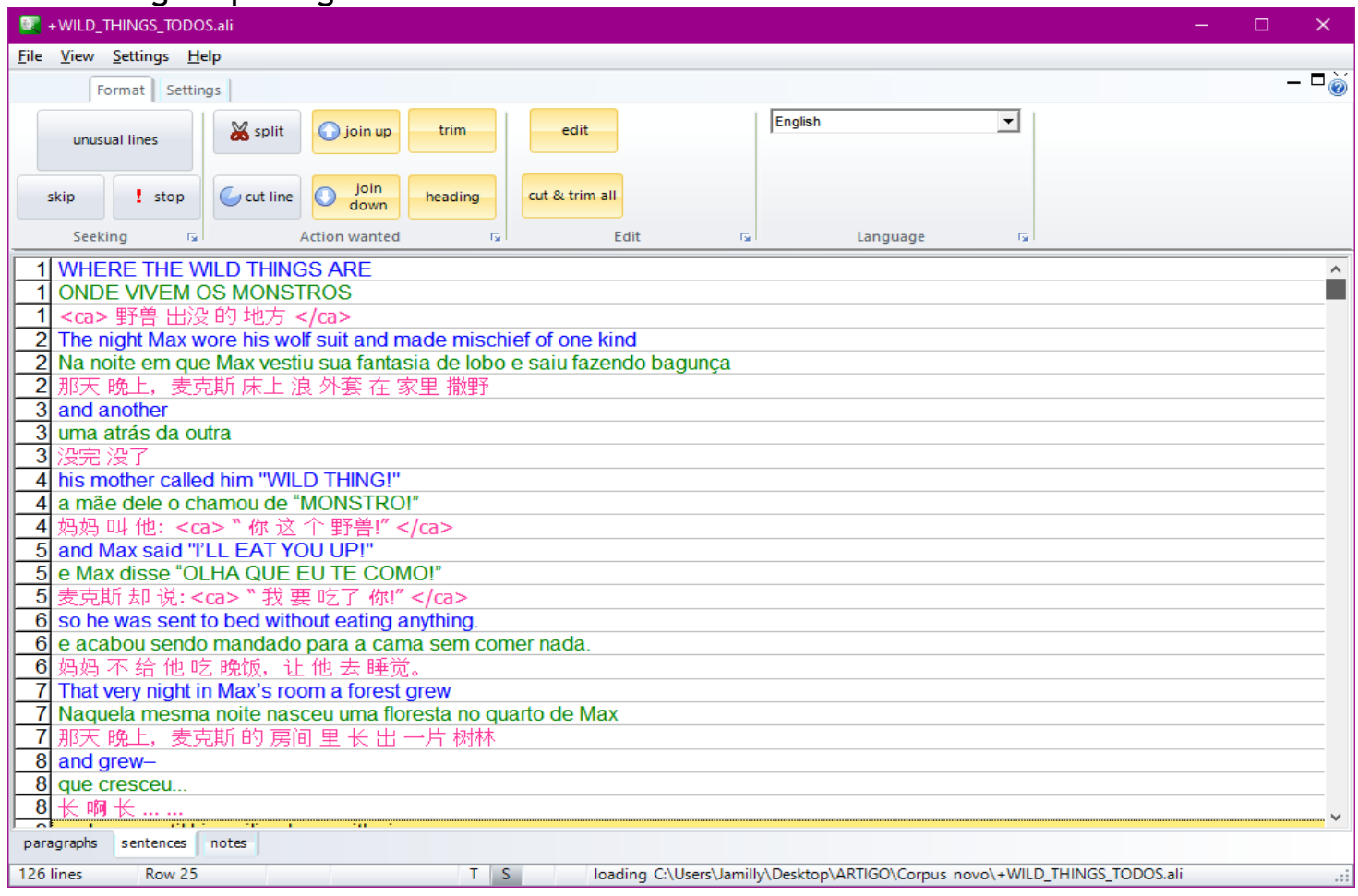

TradTerm, São Paulo, v.37, n. 2, janeiro/2021, p. 563-595

Número Especial - Linguística de Corpus

www.revistas.usp.br/tradterm 
Figura 9: Alinhamento trilíngue revisado dos primeiros 7 parágrafos inglês/português/chinês.

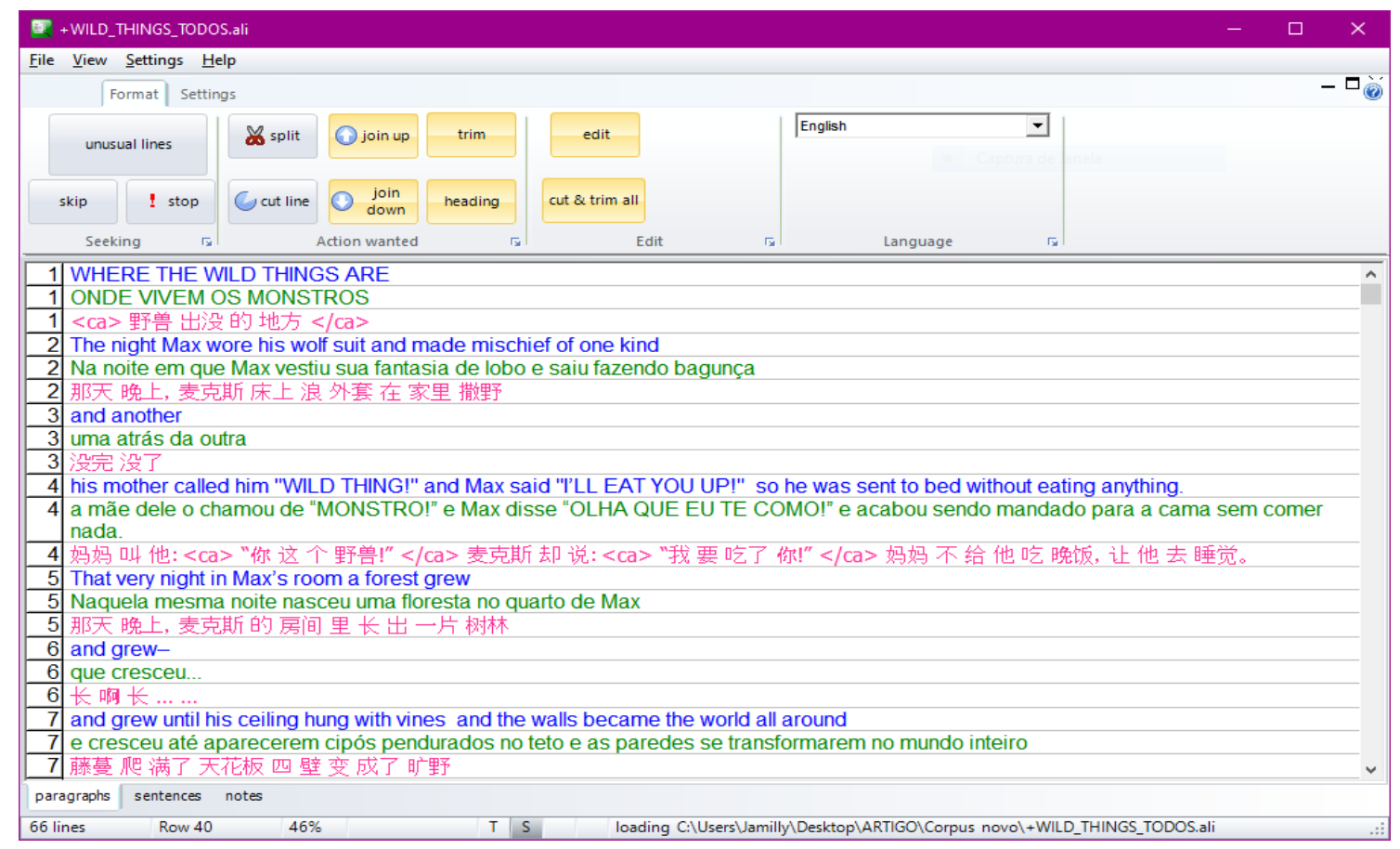

$\mathrm{O}$ alinhamento revelou que tanto o texto original quanto as traduções são compostas por 42 sentenças e 22 parágrafos, indicando, portando, a proximidade entre os textos.

Com a análise do alinhamento foi possível perceber que as quebras de sentenças e pontuações na obra original foram igualmente mantidas nas traduções, bem como as palavras enfatizadas por caixa-alta, sinalizadas na tradução em chinês com a tag <ca> (Fig. 9, linhas 1 e 4). Sendo assim, a entonação, o andamento e as pausas idealizadas por Sendak foram conservadas.

No aspecto tradutológico, o alinhamento tornou explícitas as escolhas tradutológicas para 'good things to eat': em português 'coisa boa de comer' e em chinês 'hǎo chī dōngxi 好吃东西', coisa gostosa de comer (Fig. 10, linhas 29).

TradTerm, São Paulo, v.37, n. 2, janeiro/2021, p. 563-595

Número Especial - Linguística de Corpus

www.revistas.usp.br/tradterm 
Figura 10: Alinhamento trilíngue revisado - a construção 'good things to eat' e o verbo 'to love'

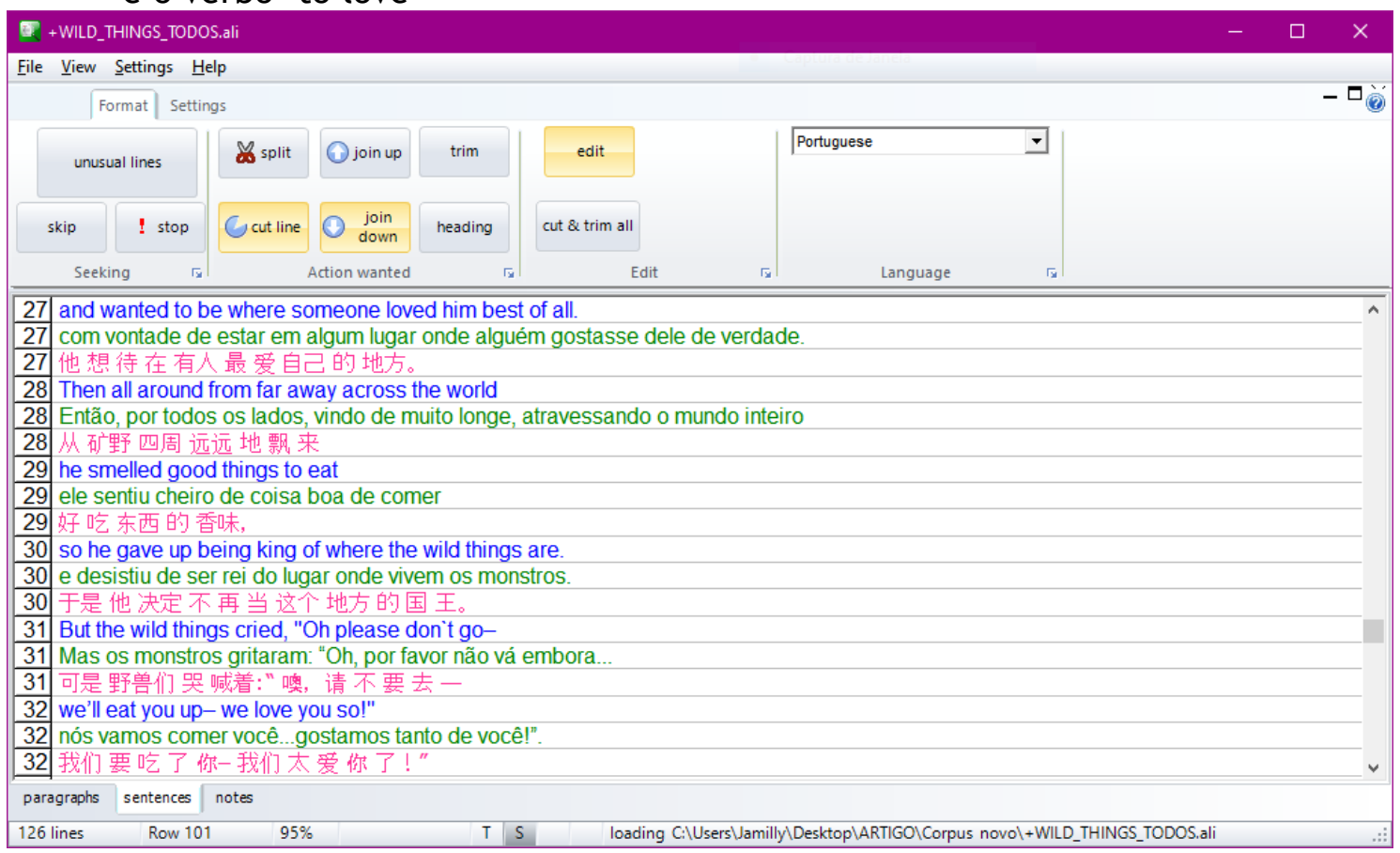

Ademais, a diferença entre as traduções do verbo 'to love' fez-se evidente: enquanto em chinês o tradutor manteve o verbo amar - ‘ài 爱', em português foi utilizado o verbo 'gostar' (Fig. 10, linhas 27 e 32).

Tanto na Wordlist, quanto no alinhamento, a nomeação das criaturas inventadas por Sendak também chama a atenção: 'wild things' foi traduzido como 'monstros' em português e como 'yěshòu 野兽', em chinês, o que, segundo o Pleco, significa wild beast - animal selvagem, besta ou até mesmo fera (Fig.3, linhas 7, 5 e 5, respectivamente; Fig.8, linhas 1; Fig.10, linha 31).

Diante de tamanha divergência nas traduções que nomeiam os personagens, outras informações sobre essa construção foram procuradas nos mais diversos materiais e meios. Descobriu-se uma entrevista concedida à Martha Stewart Living Television ${ }^{27}$ na qual o autor declarou que as criaturas que havia desenhado em sua obra foram inspiradas em parentes distantes, os quais, ainda que com dentes largos e cabelos desgrenhados, comportavam-se com certa afetividade exacerbada por meio de abraços e apertos de bochecha, assim como descrito no livro.

${ }^{27}$ Disponível em: https://youtu.be/vid. Informação também disponível em Lanes (1987: 87).

TradTerm, São Paulo, v.37, n. 2, janeiro/2021, p. 563-595

Número Especial - Linguística de Corpus

www.revistas.usp.br/tradterm 
Inicialmente, o título da obra seria Where the Wild Horses Are, contudo, Sendak não sabia como desenhar cavalos e, por isso, quando questionado por sua editora, respondeu que sabia desenhar coisas e apenas coisas. A obra, então, passou a ser intitulada Where the Wild Things Are e assim foi publicada.

Entretanto, as traduções não seguem o que havia sido desejado pelo autor. Sabendo que a tradução literal do vocábulo 'thing' seria possível tanto no chinês - 'dōngxī 东西'- quanto no português - 'coisa' - buscou-se contatar os tradutores para que se entendesse a solução tradutológica empregada por ambos.

No caso da tradução do português brasileiro, a tradutora Heloisa Jahn foi contatada por e-mail e, gentilmente, respondeu que:

0 uso da tradução 'monstros' para 'wild things' surgiu de uma sugestão da editora Bel Coelho, na época editora de infantis na Cosac. Minha primeira versão usava singela e literalmente "coisas selvagens". Bel sugeriu "monstros" e gostei da ideia, pensando que para uma criança -- e também para os adultos --, à luz da psicanálise as coisas selvagens, ou seja, o que não tem controle e amedronta, é chamado de monstros. Os monstros que nos habitam: os medos, as pulsões, os fantasmas que desconhecemos e não dominamos. Assim, adotei -- e agradeço -- a sugestão da editora Bel Coelho. (COMUNICAÇÃO PESSOAL)

Conforme explicitado, Jahn optou por aceitar a sugestão da editora Isabel Coelho, a qual trabalhava com o catálogo de literatura infantil da editora Cosac Naify desde $2003^{28}$. Aqui, é possível supor que, graças à sua experiência na área, a editora sabia que o vocábulo 'monstros' seria bem aceito pelo público-alvo.

Ademais, aponta-se que, também em 2009 - ano de publicação da tradução em português brasileiro, grandes nomes da literatura infantil brasileira publicaram livros que trouxeram o vocábulo 'monstro' em seus títulos. São exemplos: $O$ Monstro do Quarto do Pedro, de Ruth Rocha e $O$ Pequeno Monstro, de Pedro Bandeira.

Quanto à tradução para o chinês, infelizmente, não foi possível contatar o tradutor responsável. Ainda assim, objetivando verificar as possibilidades de nomeção dos personagens, elaborou-se um questionário de

\footnotetext{
${ }^{28}$ Informações disponíveis no Linkedln da editora Isabel Coelho: www.linkedin/belcoelho

TradTerm, São Paulo, v.37, n. 2, janeiro/2021, p. 563-595

Número Especial - Linguística de Corpus

www.revistas.usp.br/tradterm
} 
entrevista visando sua aplicação a nativos chineses. Para tanto, fizeram-se necessárias algumas etapas prévias:

\section{Entrevista}

- Elaboração do questionário de entrevista (Fig.5);

- Elaboração da Ficha de Dados dos participantes e do Termo de Consentimento Livre e Esclarecido;

- Contato com docentes da habilitação em chinês do curso de Letras da Universidade de São Paulo e também com os discentes intercambistas, nativos da China continental;

- Agendamento das entrevistas;

- Gravação individual das entrevistas com os participantes.

Figura 11: Questionário de entrevista

\begin{tabular}{l} 
ENTREVISTA \\
Mostrar a figura do livro e pedir para que o(a) entrevistado(a) responda as questões e faça o que \\
é pedido a seguir: \\
1. Como você descreve a figura? \\
2. Como nomearia a personagem? \\
Leitura do livro \\
3. Sabendo que o livro tem o público infantil como alvo, algo no texto causa estranhamento? \\
4. O autor nomeou as personagens como 野兽. O que essa palavra significa? \\
5. Essa palavra é comum? Esada na literatura infantil chinesa? \\
6. De acordo com a sua opinião, alguma das opçōes na tabela a seguir poderia nomear as \\
ilustrações? \\
(Em caso negativo, propor a questão 7 ) \\
7. Alguma outra nomeação poderia ser sugerida? \\
(Esclarecimento sobre a proposta de nomeação do autor) \\
8. Sabendo que o autor não queria que as ilustrações fossem chamadas de monstros, como \\
as "wild things" poderiam ser chamadas em mandarim? \\
9. Seria possivel utilizar a palavra 东西 para nomear as personagens? \\
\hline 动物
\end{tabular}

No total, foram entrevistadas 11 pessoas nativas de diferentes províncias da China: duas delas com mais de 45 anos de idade e nove delas com idade entre 20 e 22 anos. A amostragem coletada foi majoritariamente feminina e o parecer geral das respostas recolhidas encontra-se a a seguir:

TradTerm, São Paulo, v.37, n. 2, janeiro/2021, p. 563-595

Número Especial - Linguística de Corpus www.revistas.usp.br/tradterm 


\section{Como você descreve a figura?}

Apesar de descreverem os olhos, as garras, escamas, bicos e o grande porte dos personagens, todos os entrevistados os consideraram "fofinhos" e afirmaram não sentir medo ou preocupação.

\section{Como nomearia o personagem?}

Após a primeira observação, a maior parte dos entrevistados nomeou os personagens como 'dòngwù 动物', animal; 'sēnlínwù 森林物', animal da floresta e 'guàishòu 怪兽', animal raro, monstro ou animal místico.

3. Sabendo que o livro tem o público infantil como alvo, algo no texto causa estranhamento?

Alguns entrevistados revelaram o desuso de vocábulos e estranhamento quanto à ordem sintática de sentenças, porém, de maneira geral, declararam que a "tradução é boa" e que "as crianças poderiam ler facilmente".

4. 0 autor nomeou os personagens como 野兽. 0 que essa palavra significa?

Todos os entrevistados explicitaram que a palavra 'yěshòu 野兽' refere-se aos animais não domésticos. Alguns complementaram dizendo que "ele morde" e "vive na floresta".

\section{Essa palavra é comum? É usada na literatura infantil chinesa?}

Todos os entrevistados declararam que a palavra é comum. Afirmaram, ainda, que ela é usada na literatura chinesa e na tradução chinesa de Beauty and the Beast ${ }^{29}$.

6. De acordo com a sua opinião, alguma das opções na tabela a seguir poderia nomear as ilustrações?

Dentre as opções disponíveis, os entrevistados poderiam escolher quantas traduções julgassem pertinentes, as mais escolhidas foram 'yěshòu 野兽', utilizada na tradução oficial - 5 pessoas; 'guàishòu 怪兽', que significa animal raro, monstro ou animal místico - 5 pessoas; 'dàwù 大物', animal grande -4 pessoas e 'guàiwù 怪物', monstro fantasmagórico -4 pessoas.

\section{Alguma outra nomeação poderia ser sugerida?}

\footnotetext{
${ }^{29}$ No português-brasileiro: A Bela e a Fera.

TradTerm, São Paulo, v.37, n. 2, janeiro/2021, p. 563-595

Número Especial - Linguística de Corpus

www.revistas.usp.br/tradterm
} 
Dois dos entrevistados propuseram alternativas não disponíveis na tabela, foram elas: ‘yāojing 妖精', espírito e 'dǎodànguĭ 捣蛋鬼', “causador de problemas", segundo o entrevistado.

8. Sabendo que o autor não queria que as ilustrações fossem chamadas de monstros, como as "wild things" poderiam ser chamadas em mandarim?

Apenas três das pessoas entrevistadas propuseram novas nomeações. As sugestões foram 'yănshòu 魔兽', animal do pesadelo; 'dăodánguǐ 捣蛋鬼', “causador de problemas” e 'guàidōngxi 怪东西', coisa estranha.

\section{Seria possível utilizar a palavra 东西 para nomear os personagens?}

Apenas uma pessoa entrevistada afirmou que o uso do vocábulo 'dōngxi 东 西' que, segundo o aplicativo Pleco, significa thing - coisa, seria viável, pois "a criança não vai saber que coisa é até abrir o livro e começar a ler". Três pessoas afirmaram que o uso do vocábulo seria inapropriado, já que pode ser utilizado coloquialmente com sentido conotativo negativo. Os outros entrevistados tampouco o consideraram adequado, pois esse vocábulo é "usado para coisas que não se mexem", ou seja, seres inanimados.

Dadas as informações levantadas, intentou-se verificar a possibilidade de traduções literais para 'things' e, por isso, pesquisas foram feitas nos sites de venda de livros brasileiros e chineses, a partir das palavras de busca 'coisa' e 'dōngxi 东西'.

Observou-se que muitos títulos apresentam esses vocábulos, contudo, não o utilizam para nomear personagens, mas sim para referir-se a objetos ou aspectos de fala e ação. São exemplos: Yīqǐ fēnxiăng hăo dōngxi 一起分享好 东西 - Compartilhar juntos coisas boas - de Wáng Xiăomíng 王晓明; Xiăo dōngxi 小东西 - Pequenas coisas - de Zhéyě 哲也; Coisas de mãe, de Silvia Alves; Amigo não é pra essas coisas, de Alexandra Lopes, entre outros.

Os dados coletados tornaram perceptível a estranheza que a tradução literal causaria nos leitores brasileiros e chineses, ainda que, no Brasil, o vocábulo 'coisas' seja utilizado comumente para variadas designações. Entretanto, conforme apresentado no alinhamento, as escolhas lexicais

TradTerm, São Paulo, v.37, n. 2, janeiro/2021, p. 563-595 Número Especial - Linguística de Corpus www.revistas.usp.br/tradterm 
anularam o contraste que existia no texto original entre 'wild things' e 'good things'.

Afirma-se, por fim, que ambos os tradutores aplicaram a estratégia de domesticação nas traduções de 'wild things' - 'monstros', em portuguêsbrasileiro e 'yěshòu 野兽', fera, em chinês - já que utilizaram vocábulos consolidados na literatura infantil de seus respectivos países.

\section{Considerações finais}

A Linguística de Corpus, metodologia aqui empregada, demonstrou-se um elemento necessário e facilitador, visto que a mesma coleta de dados estatísticos seria inviável se realizada manualmente, pois conteria erros e demandaria maior tempo de execução. Com o uso da ferramenta Wordlist, foi possível constatar que o nome do personagem principal, Max, foi mantido em ambas as traduções, porém transliterado para o chinês de acordo com sua fonética: 麦克斯[Màikèsī]. Aqui, observou-se a aplicação da estratégia de estrangeirização, elucidada por Venuti. Complementarmente, a partir dos dados expostos, levantou-se a hipótese de traduções alternadas pra 'wild things' no texto em chinês.

Para que a hipótese fosse comprovada, utilizou-se a ferramenta Concord e, as linhas de concordância expostas por ela não apenas confirmaram a hipótese citada, como também ressaltaram o uso da construção 'good things', explícita apenas nas linhas de concordância geradas a partir do texto original.

Objetivando verificar as traduções para essa construção e, possivelmente, encontrar outros aspectos a serem analisados, foi realizado o alinhamento dos textos com a ferramenta Aligner, o qual, em seguida, foi revisado manualmente. Com o alinhamento pronto, as traduções empregadas para a construção 'good things to eat' foram verificadas: em português, 'coisa boa de comer' e em chinês, 'hăo chī dōngxi 好吃东西', coisa gostosa de comer. Observou-se, ainda, que ambos os tradutores optaram por manter o padrão frásico da obra original, respeitando, assim, as quebras de sentenças e,

TradTerm, São Paulo, v.37, n. 2, janeiro/2021, p. 563-595

Número Especial - Linguística de Corpus

www.revistas.usp.br/tradterm 
consequentemente, a entonação, o andamento e as pausas idealizadas por Sendak, como pôde ser comprovado por meio da leitura das traduções ${ }^{30}$.

Já no recorte dado às traduções de 'wild things', especificamente quanto à tradução para o chinês, constatou-se que, apesar de os entrevistados afirmarem que as ilustrações não são associadas ao medo ou a animais ferozes, os falantes nativos chineses concordam com o uso do vocábulo 'yěshòu 野兽', o qual traz o sentido de monstro, fera ou animal selvagem; há, portanto, contradição por parte dos próprios entrevistados.

O uso do vocábulo 'dōngxi 东西', coisa, foi cogitado por apenas um entrevistado, mesmo após a explanação de que o autor não desejava que seus personagens fossem nomeados como monstros. Diferentemente do português e do inglês, a língua chinesa carrega restrições quanto ao uso desse vocábulo, já que ele é quase que exclusivamente aplicado para seres inanimados.

Quanto à tradução para o português, Heloisa Jahn optou por aceitar a sugestão da editora Isabel Coelho e, de acordo com os dados coletados por meio das pesquisas complementares, de fato, o vocábulo 'monstro' demonstrou ser de uso comum na literatura infantil brasileira, seja traduzida ou original.

As pesquisas realizadas com o vocábulo 'coisa' como palavra de busca em sites de venda de livros revelaram que o vocábulo traria um possível estranhamento para os leitores brasileiros e chineses, já que, em nenhuma das duas culturas, é utilizado como forma de nomeação.

Com o conjunto de informações citadas, constatou-se que a estratégia de domesticação foi aplicada na tradução de 'wild things' para o português brasileiro - 'monstros', tal como para o chinês - 'yěshòu 野兽'.

Quanto aos encaminhamentos possíveis, a pesquisa realizada poderá ser aprofundada a partir das impressões de crianças chinesas e brasileiras, com o intuito de investigar a aceitação dos vocábulos e a correspondência entre as traduções de 'wild things' e as ilustrações propostas.

\footnotetext{
${ }^{30}$ Há vídeos disponíveis no youtube com a leitura da obra original e das traduções. Algumas possibilidades são: youtube.com/wtwta-ing (inglês), youtube.com/wtwta-ing (português) e youtu.be/wtwta-ch (chinês - lido por uma criança).
}

TradTerm, São Paulo, v.37, n. 2, janeiro/2021, p. 563-595

Número Especial - Linguística de Corpus

www.revistas.usp.br/tradterm 
Por fim, a partir dos corpora expostos e de seus respectivos alinhamentos, dentro das possibilidades de análise que não puderam ser contempladas no presente estudo, sugerimos que investigações futuras tratem das rimas do texto original e das suas respectivas traduções ${ }^{31}$, bem como da relação entre as imagens e as construções das traduções.

${ }^{31}$ Esse tipo de pesquisa foi realizada com as traduções de Where the Wild Things Are para sueco, finlandês, alemão, italiano e espanhol por Oittinem, Garavini e Ketola (2018:148-166).

TradTerm, São Paulo, v.37, n. 2, janeiro/2021, p. 563-595

Número Especial - Linguística de Corpus

www.revistas.usp.br/tradterm 


\section{Referências}

AZENHA JUNIOR, J. Tradução \& literatura infantil e juvenil. In: AMORIM, L., RODRIGUES, C.; STUPIELLO, É., (orgs.) Tradução \&: perspectivas teóricas e práticas [online]. São Paulo: Editora UNESP; São Paulo: Cultura Acadêmica, 2015: 209-232. Disponível em: <http://books.scielo.org/id/6vkk8/pdf/amorim-978856833461410.pdf>. Acesso em: 25 abr. 2020.

BARbosa, H. G.; Wyler, L. BRAZILIAN TRADITION. IN: BAKER, M. (Ed.) Routledge Encyclopedia of Translation Studies. London/New York: Routledge, 1998: $326-332$.

Berber Sardinha, T. Linguística de Corpus. São Paulo: Manole, 2004.

CECH, J. Maurice Sendak and "Where the Wild Things Are": A Legacy of Transformation. PMLA, v. 129, n. 1, NY, jan/2014, pp. 104-106. Disponível em:

<https://www.jstor.org/stable/24769425?seq=1\#metadata_info_tab_c ontents >. Acesso em: $20 \mathrm{abr} .2020$.

Coelho, N. N. A literatura infantil: história, teoria e análise. 4 ed. São Paulo: Quíron, 1987.

Coelho, N. N. Literatura: arte, conhecimento e vida. São Paulo: Peirópolis, 2000.

Debus, E. S.; Torres, M. H. Sobre a tradução de livros infantis e juvenis. Cadernos de Tradução, v. 36, n. 1, Florianópolis, dez. 2015, p. 10-15. Disponível em:

<https: / / periodicos.ufsc.br/index.php/traducao/article/view/21757968.2016v36n1p10/31104>. Acesso em: 18 abr. 2020.

FANTINUOLI, C.; ZANetTIN, F. (eds.). 2015. Creating and using multilingual corpora intranslation studies. In Fantinouli; Zanettin (eds.) New directions in corpus-based translation studies. Freie Universität Berlin, 2015: $1-9$.

HunT, P. (ed). Understanding Children's Literature. NY: Routledge, 2005.2 ed.

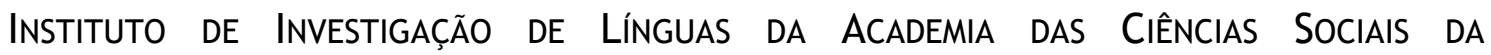
CHINA. Xiàndài hànyǔ cídiăn 现代汉语词典 [Dicionário do Chinês Moderno]. Pequim: The Commercial Press, 2012. Sexta edição.

JatoвÁ, J. R. Poéticas do Traduzir a, na e para a China: uma proposta. Cadernos de Tradução, v. 39, Florianópolis, 2019, pp. 120147. Disponível em: <https://periodicos.ufsc.br/index.php/traducao/article/view/21757968.2019v39nespp120>. Acesso em: 20 jun. 2020 TradTerm, São Paulo, v.37, n. 2, janeiro/2021, p. 563-595

Número Especial - Linguística de Corpus www.revistas.usp.br/tradterm 
LANES, S. G. The Art of Maurice Sendak. NY: Harry N. Abrams, 1984. 2 ed.

Love, M. Pleco Software. Nova York, 2000.

Menezes Junior, A. J. B.; Chen Chen, F. Wang Wei e o Mistério do Musgo Verde Azulado. Cadernos de Tradução, v. 39, Florianópolis, 2019, pp. 248258. Disponível em:

<https: / / www.scielo.br/scielo.php?script=sci_arttext\&pid=S217579682019000400248>. Acesso em: 20 jun. 2020.

NEL, P. Wild Things, I Think I Love You: Maurice Sendak, Ruth Krauss, and Childhood. PMLA, Vol. 129, No. 1, New York, janeiro/2014, pp. 112116. Disponível em:

<https://www.jstor.org/stable/24769428?seq=1\#metadata_info_tab_c ontents> Acesso em: 19 abr. 2020.

O'Sullivan, E. Historical Dictionary of Children's Literature. Historical Dictionaries of Literature and the Arts, No. 46. United Kingdom: Scarecrow Press, 2010.

Oittinen, R.; ketola, A.; Garavani, M. Translating Picturebooks: Revoicing the Verbal, the Visual, and the Aural for a Child Audience. New York: Routledge, 2018.

PASCUA-FEBLES, I. Translating Cultural References: The Language of Young People in Literary Texts. In: Van Collie, J.; Verschueren, W. P. (eds). Children's literature in translation: challenges and strategies. New York: Routledge, 2006: 111-122.

RochA, P. A. As primeiras traduções de livros para crianças no brasil. Revista Anthesis, n. 10, v. 5, São Paulo, 2017, pp. 1-5. Disponível em: <https://periodicos.ufac.br/index.php/anthesis/article/view/617>. Acesso em: 18 abr. 2020.

SCHLEIERMACHER, F. Sobre os diferentes métodos de traduzir. Tradução de Celso Braida. Princípios, v. 14, n. 21, Natal, jan./jun. 2007, pp. 233-265. Disponível em: <https://periodicos.ufrn.br/principios/article/view/500>. Acesso em: 10 abr. 2020.

ScotT, M. WordSmith Tools version 6. Stroud: Lexical Analysis Software, 2012.

TradTerm, São Paulo, v.37, n. 2, janeiro/2021, p. 563-595

Número Especial - Linguística de Corpus

www.revistas.usp.br/tradterm 
Sendak, M. Onde vivem os monstros. Tradução de Heloisa Jahn. São Paulo: Cosac Naify, 2a ed., 2014.

SendAK, M. Where the Wild Things Are. Estados Unidos da América: Harper USA, $25^{\mathrm{a}}$ ed., 1988.

SENDAK, M. 野兽出没的地方 [Where the Wild Things Are]. Tradução de AJia. China: Ming Tian Shuan She / Tsai Fong Books, 2009.

Silva-ReIS, D.; Milton, J. História da Tradução no Brasil: percursos seculares. Translatio, n. 12, Porto Alegre, 2016, pp. 2-42. Disponível em: <https://seer.ufrgs.br/translatio/article/view/69413>. Acesso em: 20 jun. 2020.

Sproviero, M. B. Alguns Tópicos e Problemas de tradução da Língua Chinesa. Revista de Estudos Orientais, n. 5, São Paulo, 2006, pp. 3758. Disponível em: <https://social.stoa.usp.br/articles/0016/4758/REO_05_2006_Alguns_TA_picos_e_Problemas_de_TraduA_A_O_da_LA_ngua_Chinesa. pdf >. Acesso em: 20 jun. 2020.

TAGnIN, S. E. O; TEIXEIRA, E. (2004). Linguística de Corpus e Tradução Técnica Relato da montagem de um corpus multivarietal de culinária. Tradterm, 10, São Paulo, dez. 2004, pp. 313-358. Disponível em: <http://www.revistas.usp.br/tradterm/article/view/47184>. Acesso em: 15 abr. 2020.

TAGNIN, S. E. O. O jeito que a gente diz: combinações consagradas em inglês e português. São Paulo: Disal, 2013.

VENUTI, L. The Translator's invisibility: a history of translation. London \& New York: Routledge, 1995.

Viana, V.; Tagnin, S. E. O. (Org.). Corpora na Tradução. São Paulo: Hub Editorial, 2015.

WAH, W. Y.; Ho, L. China. In: Hunt, P. (ed.) International Companion Encyclopedia of Children's Literature. New York: Routledge, 2005: 819-825. Segunda Edição.

Williams, J.; Chesterman, A. THE MAP: A Beginner's Guide to Doing Research in Translation Studies. Manchester: St. Jerome, 2002/2007.

TradTerm, São Paulo, v.37, n. 2, janeiro/2021, p. 563-595

Número Especial - Linguística de Corpus

www.revistas.usp.br/tradterm 
YANG, J-K.; YANG, L-C. How Words and Pictures Work in the Translation of Maurice Sendak's Picture Books. 北市大語文學報 TMUE Journal of Language and Literature 1.6, Taipei, jun/2011, pp. 17-34. Disponível em:

$<$ https://www.academia.edu/5056960/How_Words_and_Pictures_Wor k_in_the_Translation_of_Maurice_Sendaks_Picture_Books $>$. Acesso em: 20 abr. 2020.

ZILBERMAN, R.; LAJOLO, M. Um Brasil para crianças: para conhecer a literatura infantil brasileira, história, autores e textos. São Paulo: Global, 1993.

Recebido em: 30/04/2020

Aceito em: 07/06/2020

Publicado em janeiro de 2021

TradTerm, São Paulo, v.37, n. 2, janeiro/2021, p. 563-595

Número Especial - Linguística de Corpus

www.revistas.usp.br/tradterm 